\title{
Anticipation, Tax Avoidance, and the Price Elasticity of Gasoline Demand
}

\author{
$+$

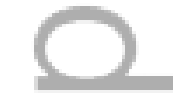 \\ August 25, 2015 \\ John Coglianese ${ }^{1}$ \\ Lucas W. Davis ${ }^{2}$ \\ Lutz Kilian $^{3}$ \\ James H. Stock ${ }^{4}$ \\ 0 \\ Lutz Kilian

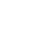 \\ (a)

\begin{abstract}
Least-squares estimates of the response of gasoline consumption to a change in the gasoline price are biased toward zero, given the endogeneity of gasoline prices. A seemingly natural solution to this problem is to instrument for gasoline prices using gasoline taxes, but this approach tends to yield implausibly large price elasticities. We demonstrate that anticipatory behavior provides an important explanation for this result. Gasoline buyers increase purchases before tax increases and delay purchases before tax decreases, rendering the tax instrument endogenous. Including suitable leads and lags in the regression restores the validity of the IV estimator, resulting in much lower elasticity estimates.
\end{abstract}

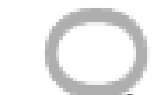

KEY WORDS: IV; price elasticity of demand; gasoline; anticipation; intertemporal substitution; storage.

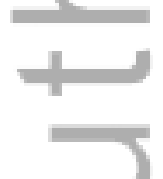

${ }^{1}$ John F. Kennedy School of Government, Harvard University, Littauer Center, 1805 Cambridge Street, Cambridge, MA 02138. Email: coglianese@fas.harvard.edu. Phone: (339) 368-1480.

${ }^{2}$ Haas School of Business, University of California, Berkeley, CA 94720, Energy Institute at Haas, and National Bureau of Economic Research. Email: 1davis@haas.berkeley.edu.

This is the author manuscript accepted for publication and has undergone full peer review but has not been through the copyediting, typesetting, pagination and proofreading process, which may lead to differences between this version and the Version of Record. Please cite this article as doi: $10.1002 /$ jae. 2500

This article is protected by copyright. All rights reserved. 
${ }^{3}$ Department of Economics, University of Michigan, Lorch Hall, Ann Arbor, MI 48109, and Centre for Economic Policy Research. Email: lkilian@umich.edu.

${ }^{4}$ Department of Economics and John F. Kennedy School of Government, Harvard University, Littauer Center, 1805 Cambridge Street, Cambridge, MA 02138, and National Bureau of Economic Research. Email: james_stock@harvard.edu.

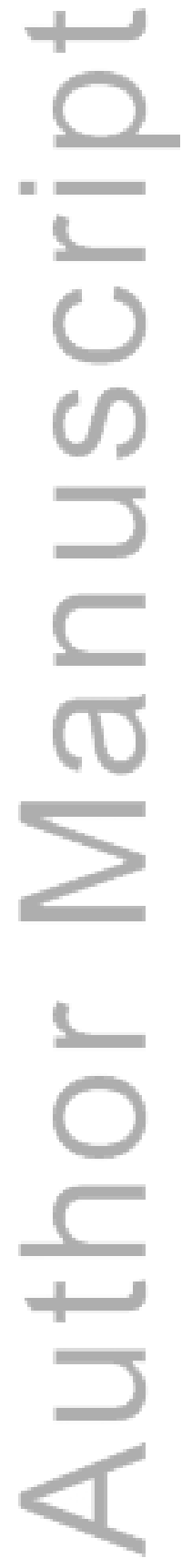




\section{INTRODUCTION}

Many economists believe that U.S. gasoline consumption in the short run is largely unresponsive to fluctuations in the retail price of gasoline. Whether this view is correct, is not self-evident. Figure 1 plots U.S. gasoline consumption since January 1974. Phases of rising real U.S. gasoline prices are shown as shaded areas. Figure 1 shows clear evidence of consumption rising during periods of falling real gasoline prices and of consumption growth slowing or consumption falling during periods of rising real gasoline prices, at least until the late 1990s. More recently, this pattern has weakened somewhat (owing in part to the fact that many gasoline price increases after 2000 were associated with a thriving economy). Nevertheless, following this sustained increase in the price of gasoline, U.S. gasoline consumption declined significantly, and consumption rebounded in the second half of 2008 when gasoline prices dropped briefly but sharply.

The central question raised by Figure 1 is how strongly U.S. gasoline consumption responds to exogenous shifts in gasoline prices. The magnitude of the short-run price elasticity of gasoline demand is of immediate policy interest. For example, the rapid decline in gasoline prices in the second half of 2014 has renewed interest in the question of how U.S. gasoline consumption will respond to the decline in retail gasoline prices (see, e.g., U.S. EIA 2015). Knowledge of this elasticity also is important for gauging the macroeconomic effects of gasoline price fluctuations (see Edelstein and Kilian 2009). Moreover, the magnitude of the price elasticity of gasoline demand plays an important role in the debate about speculation in oil markets (see Hamilton 2009; Kilian and Murphy 2014). Finally, the price elasticity is an important parameter in microeconomic models of the automobile market that are used in industrial organization and in environmental economics (see, e.g., Allcott and Wozny 2014). Estimates of the responsiveness of gasoline consumption to changes in gasoline prices must take account of the endogeneity of the price of gasoline. It is well known that increases in the demand for 
gasoline cause the price of gasoline to increase, resulting in a spurious correlation between the price and the regression error, and biasing estimates of the price elasticity toward zero. As a result, traditional leastsquares estimates of the short-run price elasticity of gasoline demand tend to be very low. ${ }^{1}$ In response to this problem, several recent studies have employed instrumental variables, but it has proven difficult to find instruments that are both highly predictive of gasoline prices and uncorrelated with demand, that is, both strong and exogenous (see, e.g., Ramsey et al.1975; Dahl 1979; Li et al. 2014; Sweeney 2015).

A seemingly natural approach is to instrument for gasoline prices using gasoline taxes. There have been more than 150 state-level gasoline tax changes in the United States since 1989 and gasoline tax changes are highly predictive of gasoline price changes. Moreover, tax changes are typically implemented with a considerable lag making it unlikely that tax changes are correlated with contemporaneous demand shocks. Puzzlingly, however, instrumental variable (IV) regressions using gasoline tax changes have yielded estimates that are unexpectedly large. In particular, Davis and Kilian (2011) report a short-run price elasticity of gasoline demand of -1.14 under a conventional IV specification. Several related studies have compared the price elasticity of gasoline demand with the tax elasticity of gasoline demand, documenting larger responses to changes in gasoline taxes than to changes in gasoline prices. For example, $\mathrm{Li}$ et al. (2014) show that gasoline consumption is at least three times as responsive to gasoline taxes as it is to non-tax changes in gasoline prices. Tiezzi and Verde (2014) report tax elasticities that are up to $48 \%$ higher than the price elasticity, and Rivers and Schaufele (2014) find that a carbon tax imposed in British Columbia generated a gasoline consumption response that was 4.9 times greater than an equivalent increase in the market price of gasoline would have been. Finally, Dieler et al. (2015) based on European data conclude that that their estimate of the tax elasticity of gasoline

\footnotetext{
${ }^{1}$ The reviews by Dahl and Sterner (1991), Espey (1998), Greene et al. (1999), Graham and Glaister (2004) and Brons et al. (2008) summarize dozens of econometric studies of this elasticity.
} 
consumption, at -0.82 , lies in the range of the results reported by Davis and Kilian and by Li et al. ($0.77)$.

The estimates of the short-run price elasticity of gasoline demand obtained using gasoline taxes as instruments are too high to be economically plausible, especially compared with the estimate of the long-run price elasticity of gasoline demand of - 0.81 found by Hausman and Newey (1995) using pooled household data. Several potential explanations have been proposed for these puzzling estimates. First, as emphasized by Davis and Kilian (2011), price changes induced by tax changes are more persistent than other price changes and thus may induce larger behavioral responses. Second, gasoline tax changes may be more salient than typical price changes because they are widely discussed in the media (e.g., Davis and Kilian, 2011; Li et al. 2014). This argument is in line with Chetty et al.'s (2009) evidence that increasing consumers' awareness of sales taxes affects consumer demand. Third, as noted by Tiezzi and Verde (2014), consumers may suffer from tax aversion (see McCaffery and Baron 2006). These three explanations are not mutually exclusive.

The current paper proposes an alternative and independent explanation. We provide evidence that these large elasticity estimates are an artifact of not having accounted for shifts in gasoline purchases in anticipation of gasoline tax changes. Tax changes are easily predicted, so forward-looking gasoline buyers will take future tax changes into account when deciding how much gasoline to buy. This anticipatory behavior applies not only to final consumers, but also to wholesale distributors and operators of retail gasoline stations, all of whom have some ability to store gasoline. We document large and statistically significant increases in gasoline purchases during the month leading up to gasoline tax increases. The pattern appears to be approximately symmetric in tax increases and decreases with gas 
purchases decreasing during the month leading up to gasoline tax decreases, though there are far fewer tax decreases in our data and this effect is not statistically significant. ${ }^{2}$

This intertemporal substitution by buyers creates an endogeneity problem that invalidates conventional IV analysis. We show that this econometric problem can be overcome by including one lead and one lag of the change in gasoline prices in the regression and including one lead and one lag of the tax instrument in the first stage IV regression. ${ }^{3}$ This approach results in a much lower and more economically plausible point estimate of the elasticity of -0.37 . Although not statistically significant, this estimate is well within the range of recent estimates of the price elasticity of gasoline demand based on alternative models and datasets that account for or minimize price endogeneity problems (see, e.g., Bento et al 2009; Tiezzi and Verde 2014; Levin et al. 2014).

The remainder of the paper is organized as follows. In Section 2, we review the problem of estimating the price elasticity of gasoline demand. Section 3 provides empirical evidence of forwardlooking behavior in the gasoline market and discusses the economic mechanisms underlying this behavior. In Section 4, we analyze the econometric implications of this evidence, we propose an alternative approach to implementing the IV estimation that remains valid in the presence of forwardlooking behavior, and we present new estimates of the short-run price elasticity of gasoline demand. Section 5 compares our preferred estimate with other elasticity estimates in the recent literature. In Section 6, we discuss implications of our analysis for future U.S. gasoline consumption. The concluding remarks are in section 7.

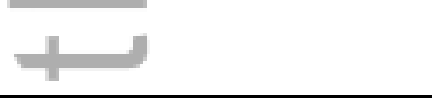

\footnotetext{
${ }^{2}$ In related work, Dieler et al. (2015) show similar anticipatory behavior using European data. They find that both gasoline and diesel purchases increase significantly in the month leading up to a fuel tax increase. Fuel purchases decrease in the exact month of the tax increase, but then increase again in the following month.

${ }^{3}$ Our approach is not without precedent. For example, Malani and Reif (2015) use a similar single-equation IV approach to model tort reforms not targeted at physicians, but likely anticipated by them.
} 


\section{BACKGROUND}

There is a large literature on estimating the price elasticity of gasoline demand in the short run and in the long run. One would expect the short-run price elasticity of gasoline demand to be much smaller than the long-run elasticity, because it takes time for consumers to fully adjust their consumption in response to higher gasoline prices (see Sweeney 1984). Typical estimates of the short-run elasticity obtained from ordinary least squares (OLS) regressions of changes in gasoline purchases on changes in gasoline prices tend to be very close to zero, however. One reason is that increases in the demand for gasoline cause the price of gasoline to increase, resulting in a spurious correlation between the price and the regression error and biasing estimates of the price elasticity toward zero. The main approach to addressing this endogeneity problem has been to instrument for gasoline prices. While this approach is appealing, the challenge has been to find instruments that are both truly exogenous and strong in the econometric sense (see Stock et al. 2002). ${ }^{4}$

Davis and Kilian (2011) proposed the use of changes in gasoline taxes by state and month as an instrument. Even though tax legislation may respond to current prices, the implementation of tax changes typically occurs with a lag, making it reasonable to assume that changes in tax rates are uncorrelated with unobserved changes in demand. In constructing tax instruments one has to be careful to exclude ad valorem gasoline taxes from the analysis because they are functionally related to price, violating the exogeneity assumption. Using U.S. data for January 1989 through March 2008, Davis and Kilian

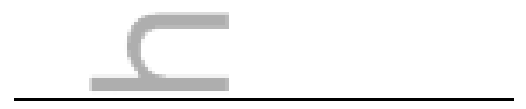

\footnotetext{
${ }^{4}$ For example, Ramsey et al. (1975) and Dahl (1979) use the relative prices of refinery products such as kerosene and residual fuel oil as instruments. As noted in Hughes et al. (2008), the problem with this approach is that the relative prices of other refinery outputs are likely to be correlated with gasoline demand shocks. Instead, Hughes et al. instrument using changes in global crude oil production such as a strike by oil workers in Venezuela in 2002. Li et al. (2014) rely on global crude oil prices as the instrument. The latter instrument is unlikely to exogenous, however. The same concern applies to the use of the exchange rate as an instrument for gasoline prices (see Dieler et al. 2015).
} 
constructed a balanced state-level panel model of 50 states and the District of Columbia and estimated a regression equation of the form

$$
\Delta q_{i t}=\beta_{0}+\beta_{1} \Delta p_{i t}+\rho_{t}+u_{i t}
$$

where changes in log gasoline purchases in state $i$ and month $t, \Delta q_{i t}$, depend linearly on changes in the after-tax price of gasoline in logs, $\Delta p_{i t}$, time fixed effects, $\rho_{t}$, and unobserved idiosyncratic state-specific time-varying factors comprising an error term, $u_{i t}$. The coefficient of interest is the price elasticity parameter $\beta_{1}$. The time fixed effects control for month-to-month variation that is the same across states. The advantage of the first-differenced model is that it is identified using month-to-month changes, not longer-run before-and-after comparisons like the fixed effects model. This makes first-differenced models inherently less susceptible to unmodeled differential trends across states.

There is, however, reason to be concerned with the endogenity of the instrument because gasoline purchases may adjust in anticipation of changes in gasoline taxes even before the tax change takes effect. For the tax instrument to be valid, it must be uncorrelated with the error term in equation (1) such that

$$
E\left(u_{i t} \Delta \tau_{i t}\right)=0
$$

where the instrument, $\Delta \tau_{i t}$, is the change in taxes in state $i$ between month $t-1$ and month $t$. In other words, the tax instrument is allowed to affect gasoline purchases only through its effect on the price of gasoline in the first-stage regression

$$
\Delta p_{i t}=\alpha_{1}+\alpha_{1} \Delta \tau_{i t}+\theta_{t}+v_{i t}
$$

We stress that the orthogonality condition (2) is violated when the quantity variable responds to taxes in future periods. In this case, a tax change in period $t$ influences the change in gasoline purchases in period $t$ not only through the change in price in period $t$, but also by having already affected gasoline purchases 
in period $t-1$. As a result, the contemporaneous change in gasoline purchases, $\Delta q_{i t}$, is larger than would have been expected for a typical price change of that magnitude, and the IV estimate of the price elasticity systematically overstates the responsiveness of gasoline purchases. The next section provides evidence for the presence of such anticipatory behavior in the U.S. gasoline market.

\section{THE EVIDENCE OF ANTICIPATORY DEMAND SHIFTS}

\subsection{An Event Study}

An event study based on the data used in Davis and Kilian (2011) allows us to quantify the importance of anticipatory shifts in gasoline purchases. Figure 2 a summarizes the typical patterns in the state-level data around the time of a gasoline tax increase. For expository purposes, the figure limits attention to nominal tax increases of at least 1 cent. The charts average over all 140 events of nominal state tax increases of at least 1 cent and plot gasoline taxes, gasoline prices, and gasoline purchases in the months immediately before, during, and after such a tax increase. The gasoline tax increase is normalized to occur in month 1. Figure $2 \mathrm{a}$ shows that gasoline prices respond to tax increases, confirming that the instrument is strong, but it also shows an increase in gasoline purchases in the month before the tax hike. Much the same pattern is obtained in Figure 2b, after restricting attention to gasoline tax increases of at least 2 cents. In fact, the magnitude of the shifts in gasoline purchases is even more pronounced, as one might have expected. As in Figure 2a, gasoline purchases spike in the month preceding the tax increase, and then drop markedly in the month of the tax increase.

This pattern is consistent with gasoline buyers filling up their tanks one last time in the days before the higher tax goes into effect. This type of anticipatory behavior also helps explain the sharp decrease in purchases observed during the month of the tax increase, as gasoline buyers enter the month with full tanks and hence are less likely to stop at a gas station. This economic interpretation suggests that conventional IV estimates overstate the extent to which consumption falls in response to the 
exogenous gasoline price increase. These estimates are biased because they take as their point of departure the excessive level of purchases immediately before the tax increase rather than the normal consumption level, when computing the response of quantity to the exogenous shift in price.

So far we have focused on gas tax increases. In the online appendix we provide the corresponding graphical evidence for tax decreases of at least one cent and at least two cents, respectively. Consistent with our proposed explanation, the change in gasoline purchases is negative in both figures in the month prior to the gasoline tax decrease becoming effective. This is what one would expect if gasoline buyers were strategically delaying their gasoline purchases in anticipation of the lower taxes in the following month. However, there is much more month-to-month variation in the event study estimates overall.

\subsection{Regression Evidence based on the Event Study}

Table 1 provides regression estimates and standard errors describing the evolution of log gasoline purchases before, during, and month after gasoline tax changes. We regress the month-to-month change in log gasoline purchases on event study indicator variables for the month before, the month during, and the month after gasoline tax changes in order to assess the statistical significance of the changes in gasoline purchases observed in Figures 2a-2d. The point estimates in column (a) show that gasoline purchases increase by a marginally significant $1.3 \%$ in the month preceding the tax increase, followed by a statistically significant drop by $3.1 \%$ in the month of the tax increase. Focusing on tax increases of at least two cents in column (b) sharpens the pattern, with a statistically significant increase of $2.1 \%$ in the month before, and a statistically significant decrease of $3.8 \%$ in the month in which the tax increase occurs. The corresponding estimate for the month following the tax increase is not statistically significant in either specification, but, especially in column (c), is large enough to potentially affect the overall impact of the gas tax increase. 
Columns (c) and (d) in Table 1 provide the corresponding evidence for gasoline tax decreases. With far fewer gasoline tax decreases, these coefficients are estimated with considerably lower precision. There are a number of reasons why one might expect less anticipatory behavior in response to tax decreasēs. Fôr example, one might expect gasoline tax decreases to lack the salience of gasoline tax increases if the latter receive more media attention. Perhaps more importantly, as a practical matter, it is much easier to fill up one's tank three days early than to wait three extra days to fill the tank.

Nevertheless, the overall pattern of the point estimates is roughly symmetric in gas tax increases and decreases. In particular in column (d), which focuses on gas tax decreases of at least two cents, there appear to be non-negligible decreases in gasoline purchases during the month before as well as during the month after the tax decrease.

\subsection{Discussion of the Observed Magnitudes}

There are several reasons why the evidence of anticipatory changes in gasoline purchases in Table 1 is economically plausible. One reason is that drivers may store gasoline in the tank of their automobile, as discussed earlier. For example, suppose that $10 \%$ of drivers were to shift forward their weekly fill-up by three days. This would amount to a shift in purchases of about $1 \%$, which is roughly consistent with the magnitude of the lead effect in column (a) of Table $1 .^{5}$

This is not the only mechanism at work, however. The anticipatory behavior in Table 1 likely reflects reactions not only by retail consumers, but also by gasoline station operators and gasoline distributors. This point is not immediately obvious, but related to the fact that gasoline purchases are measured upstream from actual sales to final consumers. Specifically, the conventionally used data on

\footnotetext{
${ }^{5}$ Suppose that gasoline purchases are uniformly distributed throughout a 30 -day month, so each day $3.3 \%$ of the monthly gasoline purchases occur. If $10 \%$ of drivers shifted forward their purchases on the last day of the month this would result in a $0.33 \%$ decrease in monthly purchases, and if $10 \%$ of drivers shifted forward their purchases on the last 3 days of the month, monthly purchases would drop by $1 \%$.
} 
gasoline purchases comes from the Petroleum Marketing Monthly Report: Prime Supplier Sales Volumes by Product and Area issued by the U.S. Energy Information Administration (EIA). Sales volumes are collected by the EIA using the EIA-782C survey, which is a monthly survey of all prime gasolinē suppliers, consisting of a small group of currently 185 firms nationwide that produce, import, or transport petroleum products across state boundaries and local marketing areas. This gasoline is then purchased by distributors for delivery to gasoline stations. As a result, data on the quantity of gasoline purchased collected by statistical agencies differs from actual gasoline purchases at the retail level (also see Levin et al. 2015).

Not only retail consumers, but also gasoline distributors and gasoline station operators have an incentive to adjust their purchase and storage choices in the days leading up to a gasoline-tax change. In particular, both have an incentive to stockpile gasoline in anticipation of gasoline tax increases, so the apparent spike in the quantity of gasoline sold prior to gasoline tax increases likely reflects not only shifts in the purchases of final consumers, but also stockpiling by gasoline distributors and gasoline stations. For example, in the days leading up to a gasoline tax increase, forward-looking distributors would be expected to fill up all their tanker trucks, and gasoline station operators would be expected to have their underground storage tanks completely filled.

\section{ECONOMETRIC IMPLICATIONS}

Our empirical findings have two important implications for the estimation of the price elasticity of gasoline demand. First, anticipatory behavior by gasoline buyers undermines the rationale for using gasoline taxes as an instrument. Intertemporal substitution causes the gasoline tax instrument to be correlated with the error term because the presence of the tax spike is correlated with the "missing" purchases that were shifted forward in the previous period, rendering the instrument endogenous. Second, because this endogeneity is the result of lag misspecification, it can be corrected by including 
leads and lags of the change in prices in the regression, along with leads and lags of the tax change as instrumental variables. The lead of the change in the gas tax, in particular, is a valid instrument for the lead of the change in the gas prices because the future tax change is known to consumers, given that it already has been legislated.

We examine the implications of these two insights in Table 2. Table 2 reports coefficient estimates and standard errors for a range of alternative IV model specifications. For comparison, Table 2 also presents these specifications estimated by OLS. The dependent variable in all five specifications is the month-to-month change in log gasoline purchases in the state. All models control for month-ofsample fixed effects (time effects) and the change in state-level unemployment. Standard errors are clustered at the state level. Columns (1)-(3) include the contemporaneous change in log gasoline price only, without a lead or lag. Column (1) presents OLS estimates and column (2) instruments for the change in the log gasoline price using the contemporaneous change in the log tax, whereas column (3) adds, as additional instruments, the lead and lag of the change in the log tax. The coefficient estimates in columns (2) and (3) are nearly identical. In both cases the model yields an implausibly large price elasticity of -1.14. The estimates in columns (1)-(3) essentially replicate the findings in Davis and Kilian (2011) for a similar specification.

( We already provided direct evidence that an empirical specification including only contemporaneous values would be misspecified. A complementary approach to documenting this endogeneity is to test the overidentifying restrictions for the model in column (3), which includes more instruments than endogenous regressors and hence is overidentified. Based on Hansen's $J$-statistic, we

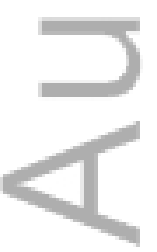


reject the null hypothesis that the instruments are exogenous at the 5\% significance level. ${ }^{6}$ When the coefficients are overidentified, the two stage least squares estimator and GMM estimator differ in general; in the case of regression (3), the GMM estimator of coefficient on the change in log price is -0.98 , slightly less elastic than (and more precisely estimated than) the two stage least squares estimator, but the two estimates are within a standard error of each other and are not qualitatively different.

= As discussed earlier, the endogeneity of the tax instrument is the result of lag misspecification, so it can be corrected by including leads and lags of the change in price, along with leads and lags of the change in tax as instrumental variables. Our empirical evidence in section 3 suggests that including one lead and one lag of the change in gasoline prices is sufficient. The reason is that, in the presence of forward-looking behavior, one would expect gasoline purchases during the lead month to be unusually high and purchases during the month of the tax increase to be unusually low. Only in the month after the tax change the behavioral response to the tax change becomes apparent, necessitating the inclusion of the lagged term.

Results for the specification with one lead and one lag can be found in column (4) and (5) for OLS and IV estimation, respectively. The IV coefficient on the contemporaneous change in log price changes very little under this augmented specification, but the coefficients for both the lead and the lag are positive. The former, in particular, is also statistically significant. Table 2 also reports estimates of the cumulative effect of the tax change on gasoline purchases, calculated by summing the estimates of the lead, contemporaneous, and lag coefficients. Including the lead and the lag in the IV regression reduces the cumulative effect of a gasoline tax change to -0.37 . This estimate is much smaller than the cumulative

\footnotetext{
${ }^{6}$ The $J$-statistic is computed using the two-step GMM estimator with a weight matrix of the inverse of the long-run variance matrix estimated using clustered standard errors, where the time dummy variables are projected out in an initial step.
} 
effect in columns (2) and (3) because the sharp contemporaneous decrease in gasoline purchases is largely offset by the increases in purchases during the month before and the month after the tax change is implemented. It is also statistically insignificant. The first-stage $F$ and Cragg-Donald weak-instrument statistics are all large, exceeding the Stock-Yogo (2005) critical values, which suggest that the results in Table 2 do not suffer from weak instrument problems. ${ }^{7}$

= Table 3 reports variations on regression (5) using alternative sets of instruments as sensitivity checks. First, as a specification check, regression (6) includes two leads and two lags of the tax change as instruments. Recall that adding a lag and a lead of tax changes to regression (2) resulted in a rejection of the overidentifying restrictions in regression (3). In contrast, the analogous augmentation of the instruments in regression (6) fails to reject the overidentifying restrictions $(J$-statistic $p$-value $=.296$ ), and the two-stage least squares and GMM estimates of the cumulative effect are respectively -0.360 and 0.314 , both close to the estimate in regression (5). Thus the results in regression (6) provide confirmatory evidence that the original specification problem is resolved by including one lead and one lag of price changes.

A reasonable conjecture is that negligible changes in the nominal gasoline tax do not matter to gasoline buyers. Column (7) considers an alternative specification in which we instead instrument using an indicator variable for state-month observations in which there was a nominal gasoline tax change of at least 2 cents. For this specification we include two separate indicators, one for tax increases of at least 2 cents, and one for tax decreases by at least 2 cents. With this model we find a slightly lower and again

\footnotetext{
${ }^{7}$ The first stage $F$ and Cragg-Donald statistics are computed under the assumption of homoscedasticity and no serial correlation, so that they can be compared to the Stock-Yogo (2005) critical values, which are valid only under homoscedasticity and no serial correlation. Because there is evidence of serially correlated errors in these regressions, these statistics are only illustrative. However we note that for all the regressions discussed here, except for regression (9) in Table 3, these statistics far exceed both the Stock-Yogo critical values and the rule-of-thumb value of 10 , thus suggesting that for all but regression (9) the instruments are strong.
} 
imprecisely estimated cumulative effect of -0.29 . Columns (8) and (9) consider tax increases and tax decreases separately. With tax increases in column (8), the results are very similar to regressions (5) and (7) suggesting that the results are largely driven by tax increases over 2 cents. With tax decreases in column (9) the point estimates are again similar, with a somewhat larger cumulative effect of -0.41 , but the estimates are extremely imprecise. In contrast to the other IV regressions in Tables 2 and 3, the CraggDonald statistic for regression (9) suggests that the instruments are weak. This finding is not surprising given that there are only 14 incidents of such gasoline tax declines in the sample. Finally, column (10) includes as instruments the interaction between the change in the log tax and an indicator variable for gasoline tax increases of at least two cents, along with its lead and lag. One might have expected there to be a differential response of prices to gasoline tax increases of at least two cents. As it turns out, however, the estimates are extremely similar with this alternative specification. The interaction term is statistically insignificant in all of the first-stage equations, and the estimated cumulative effect is very similar, with a value of -0.34 compared to -0.37 . Similarly to the augmented instrument set in regression (6), the $J$ statistic does not reject the overidentifying restrictions test, further supporting the adequacy of the dynamic specification including a lead and lag of price changes.

We made the case that including one lead and one lag of the change in price makes sense a priori on economic grounds. Although we know that the responsiveness of gasoline buyers may increase over time, it seems implausible that such longer-run adjustments would occur within the first months of a tax change. Consistent with this reasoning, it can be shown that adding more lags (or another lead) to the regression model reduces the cumulative effect somewhat and renders the estimates less statistically significant, but none of these additional lead and lag terms are statistically significant, consistent with the evidence in Table 1.

\section{A COMPARISON WITH OTHER ELASTICITY ESTIMATES}


Our analysis adds to a growing literature that suggests that gasoline buyers are more responsive to gasoline prices than recent studies such as Hughes et al. (2008) have indicated. There is a surprising degree of agreement even among studies using very different structural estimation methodologies. Our preferred point estimate of -0.37 (Table 2, regression (5)), for example, is close to the estimate of -0.35 for the price elasticity of gasoline demand reported in Bento et al. (2009) based on a microeconomic model of the markets for new, used, and scrap vehicles, which may be viewed as a short-run price elasticity effectively because it is conditional on the composition of the car fleet.

In related work, Tiezzi and Verde (2014) show that single-equation estimation methods based on time series data tend to underestimate price elasticities by about $20 \%$ compared with estimates from systems of demand equations using cross-sectional data. Their system-based estimate of the one-month own price elasticity of gasoline demand is -0.50 , which would imply a single-equation estimate of -0.40 , only slightly higher than our point estimate of -0.37 .

Finally, our estimate is also consistent with recent evidence in Levin et al. (2015). Levin et al. use daily expenditure data from 243 U.S. cities based on credit card transactions that occurred between February 1, 2006 and December 31, 2009 to estimate the price responsiveness of the daily demand for gasoline to changes in daily gasoline prices. Their approach thus addresses the measurement issues with the gasoline quantity data we discussed in section 3. For a panel of U.S. states, they arrive at monthly elasticity estimates of between -0.22 and -0.30 , depending on how purchases at the pump are treated, even without accounting for price endogeneity. These estimates are two or three times as high as OLS estimatês based on more aggregate data, consistent with our conjecture that stockpiling by gasoline stations and gasoline distributors is an important feature of the data.

There is also a link between our analysis and the related literature on the short-run price elasticity of demand for crude oil. Kilian and Murphy (2014) report a point estimate of - 0.25 for the short-run price 
elasticity of oil demand in global oil markets obtained from a structural vector autoregression. Given that crude oil accounts for about half the U.S. retail cost of gasoline, as pointed out by Hamilton (2009), one would expect the retail price elasticity of gasoline demand to be about twice that for crude oil. A reasonable conjecture is that this global price elasticity is somewhat higher than the U.S. price elasticity of oil demand. If the U.S. elasticity were two thirds of the global elasticity, for example, this would imply a price elasticity of gasoline demand of -0.33 , close to our point estimate.

\section{IMPLICATIONS FOR FUTURE U.S. GASOLINE CONSUMPTION}

The external validity of the elasticity estimate in column (5) of Table 2 for changes in the gasoline price not reflecting gasoline tax changes may be assessed based on the exogenous gasoline supply shock caused by Hurricanes Rita and Katrina in late 2005. ${ }^{8}$ The observed increase in the price of gasoline in September 2005 relative to August was $15.3 \%$. Given our elasticity estimate of -0.37 , we would have expected a decline in gasoline consumption in September of $-5.6 \%$. The actual decline was $-6.5 \%$, suggesting that our one-month price elasticity appears to fit the data quite well.

One of the rationales for estimating the price elasticity of gasoline demand is the ability to make predictions about gasoline consumption given some hypothesized exogenous change in gasoline prices. For example, an important policy question is how the steep decline in U.S. gasoline prices after June 2014 is expected to affect U.S. gasoline consumption. Whereas Hurricanes Rita and Katrina were largely unpredictable shocks, the decline in gasoline prices since June 2014 was predictable in real time to some extent (see Baumeister, Kilian and Lee 2015). In measuring the unpredictable component of the change

8 These exogenous weather events caused a shutdown of oil refineries along the Gulf coast in September 2005, resulting in a major negative gasoline supply shock (see Kilian 2010). We make the assumption that the U.S. supply of gasoline was not affected by these events before September 2005. Given that there was little warning time before these hurricanes made landfall, we proceed under the additional assumption that the shortage of gasoline was not anticipated in August. 
in gasoline prices for each month between July and December 2014, we rely on the real-time gasoline price predictions issued by the U.S. Energy Information Administration in its Short-Term Energy Outlook. ${ }^{9}$ Applying the elasticity estimate to the unpredictable component of the change in gasoline prices yields an expected cumulative increase in U.S. gasoline consumption of 8\% relative to June 2014 levels. Of course, this thought experiment presumes that the shift of the gasoline supply curve was the only change in U.S. gasoline markets after June 2014. To the extent that overall macroeconomic conditions change, the actual change in consumption could be more or less than this $8 \%$ prediction.

\section{CONCLUDING REMARKS}

The ability to store gasoline means that purchases of gasoline need not correspond to actual gasoline consumption. In this paper, we argued that this fact has important implications for the specification of gasoline demand models. Put simply, gasoline purchases respond to expected changes in gasoline prices. While most price changes are difficult to predict, gasoline tax changes are known well in advance, so forward-looking gasoline buyers will accelerate gasoline purchases in the days leading up to gasoline tax increases, and delay gasoline purchases in the days leading up to gasoline tax decreases.

This anticipatory behavior creates an endogeneity problem which undermines the validity of conventional IV estimates of the price elasticity of gasoline demand. We showed how this concern can be addressed by augmenting the regression model to include one lead and one lag of the change in log gasoline prices and augmenting the instruments with the corresponding leads and lags of the change in gasoline taxes. Using monthly data from January 1989 through March 2008, we found that the estimated

\footnotetext{
${ }^{9}$ Focusing on the unpredictable variation in the price of gasoline also helps mitigate concerns about the lack of exogeneity of U.S. gasoline prices. Baumeister and Kilian (2015) provide evidence that the U.S. gasoline price shocks between June and December 2014 were associated with global shocks to the demand for crude oil that arguably were exogenous with respect to the U.S. gasoline market, allowing us to think of the resulting unexpected declines in U.S. gasoline prices as exogenous.
} 
price elasticity decreases from an implausibly high -1.14 to a much more plausible -0.37 after including one lead and one lag. Although this estimate is imprecise (standard error $=0.24$ ), it is similar in magnitude to other recent elasticity estimates that take explicit account of the endogeneity of gasoline prices. Moreover, a simple back-of-the-envelope calculation suggests that this estimate appears to fit the data quite well.

= Our analysis has implications for other empirical applications as well. Many purchases other than gasoline are storable, allowing buyers to strategically time their purchases in anticipation of future price changes. This strategic behavior has the potential of undermining the validity of a host of seemingly exogenous candidate instruments. For example, a commonly used instrument is changes in the weather, but weather changes in turn are often predictable at a time horizon that could matter for monthly data. In such circumstances, allowing for additional leads and lags in the regression may help address the resulting endogeneity of the instrument. In addition, our results highlight that it may matter greatly how the quantity variable is measured when estimating the price elasticity of demand. This point also applies to other markets. A case in point is the natural gas market (see, e.g., Hausman and Kellogg, 2014). Unlike gasoline buyers, retail consumers of natural gas typically have no ability to store natural gas, so purchases and consumption occur at the same time. Throughout the rest of the supply chain, however, there is extensive storage capacity. Thus, short-run price elasticities of demand may differ substantially based on whether quantities are measured at the retail level or further upstream.

\section{References}

Allcott H, Wozny N. 2014. Gasoline prices, fuel economy, and the energy paradox. Review of Economics and Statistics 96: 779-795.

Baumeister C, Kilian L. 2015. Understanding the decline in the price of oil since June 2014. Manuscript, Department of Economics, University of Michigan. 
Baumeister C, Kilian L, Lee TK. 2015. Inside the crystal ball: New approaches to predicting the gasoline price at the pump. Manuscript, Department of Economics, University of Michigan.

Bento AM, Goulder LH, Jacobson, MR, von Haefen RH. 2009. Distributional and efficiency impacts of increased U.S. gasoline taxes. American Economic Review 99: 667-699.

Brons M, Nijkamp P, Pels E, Rietveld P. 2008. A meta-analysis of the price elasticity of gasoline

= demand: A SUR approach. Energy Economics 30: 2105-2022.

Chetty R, Looney A, Kroft K. 2009. Salience and taxation: Theory and evidence. American Economic Review 99: 1145-1177.

Dahl C. 1979. Consumer adjustment to a gasoline tax. Review of Economics and Statistics 61: 427is32.

Dahl C, Sterner T. 1991. Analyzing gasoline demand elasticities: A survey. Energy Economics 13: 203-210.

Davis LW, Kilian L. 2011. Estimating the effect of a gasoline tax on carbon emissions. Journal of Applied Econometrics 26: 1187-1214.

Dieler J, Jus D, Zimmer M. 2015. Fill'er up -- The effect of fuel taxes on carbon emissions. Manuscript, CESifo, Munich.

Edelstein P, Kilian L. 2009. How sensitive are consumer expenditures to retail energy prices?

Journal of Monetary Economics 56: 766-779

Espey M.1998. Gasoline demand revisited: An international meta-analysis of elasticities. Energy Economics 20: 273-295.

Federal Highway Administration. 2008. Highway Taxes and Fees: How They Are Collected and Distributed. Office of Highway Policy Information, https://www.fhwa.dot.gov/policyinformation/motorfuel/hwytaxes/2008/.

Graham DJ, Glaister S. 2004. Road traffic demand elasticity estimates: A review. Transport Reviews 
24: $261-274$.

Greene DL, Kahn JR, Gibson RC. 1999. Fuel economy rebound effect for U.S. household vehicles. Energy Journal 20: 1-30.

Hamiltôn JD. 2009. Causes and consequences of the oil shock of 2007-08. Brookings Papers on Economic Activity 1: 215-259

Hausman JA, Newey WK. 1995. Nonparametric estimation of exact consumers' surplus and deadweight loss. Econometrica 63: 1445-1476.

Hausman C, Kellogg R. 2015. Welfare and distributional implications of shale gas. Forthcoming: Brookings Papers on Economic Activity.

Hughes JE, Knittel CR, Sperling D. 2008. Evidence of a shift in the short-run price elasticity of gasoline demand. Energy Journal 29: 93-114.

Kilian L. 2010. Explaining fluctuations in U.S. gasoline prices: A joint model of the global crude oil market and the U.S. retail gasoline market. Energy Journal 31: 87-104.

Kilian L, Murphy DP. 2014. The role of inventories and speculative trading in the global market for crude oil. Journal of Applied Econometrics 29: 454-478.

Levin L, Lewis MS, Wolak FA. 2015. High frequency evidence on the demand for gasoline.

Manuscript, Department of Economics, Stanford University.

Li S, Linn J, Muehlegger E. 2014. Gasoline taxes and consumer behavior,” American Economic Journal:

Economic Policy 6: 302-342.

Malani A, Reif J. 2015. Interpreting pre-trends as anticipation: Impact on estimated treatment effects from tort reform. Journal of Public Economics 124: 1-17.

McCaffery EJ, Baron J. 2006. Thinking about tax,” Psychology, Public Policy, and Law 12: 106-135. 
Ramsey J, Rasche R, Allen B. 1975. An analysis of the private and commercial demand for gasoline.

Review of Economics and Statistics 57: 502ew of

Rivers N, Schaufele B. 2014. Carbon tax salience and gasoline demand. Forthcoming: Journal of Environmental Economics and Management.

Scott KR. 2012. Rational habits in gasoline demand. Energy Economics 34: 1713-1723.

Stock JH, Yogo M. 2005. Testing for weak Instruments in linear IV regression. In Identification and Inference for Econometric Models: Essays in Honor of Thomas J. Rothenberg, Stock JH, Andrews DWK (eds). Cambridge University Press: Cambridge.

Stock JH, Yogo M, Wright JH. 2005. A survey of weak instruments and weak identification in generalized method of moments. Journal of Business and Economic Statistics 20: 518-529.

Sweeney JL. 1984. The response of energy demand to higher prices: What have we learned? American Economic Review 74: 31-37.

Sweeney RL. 2015. Environmental regulation, imperfect competition and market spillovers: The impact

of the 1990 Clean Air Act Amendments on the U.S. oil refining industry. Manuscript, JFK School of Government, Harvard University.

Tiezzi S, Verde SF. 2014. Overreaction to excise taxes: The case of gasoline. EUI Working Paper RSCAS 2014/54. European University Institute.

U.S. Energy Information Administration. 2015. Short-Term Energy Outlook, January.

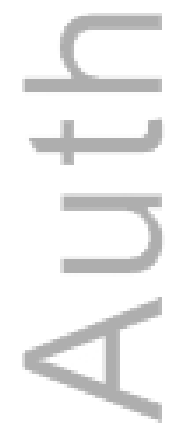




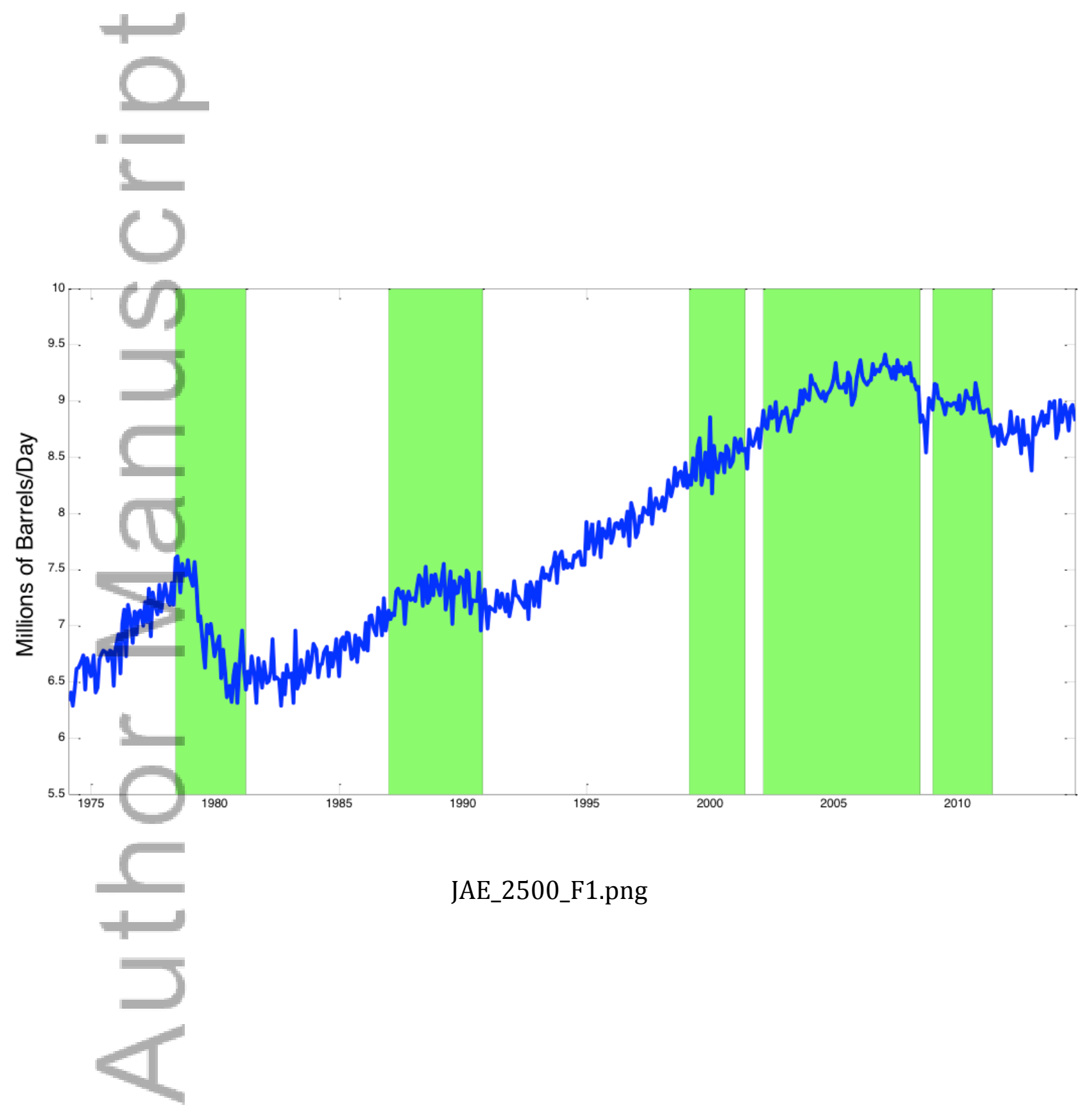

This article is protected by copyright. All rights reserved. 

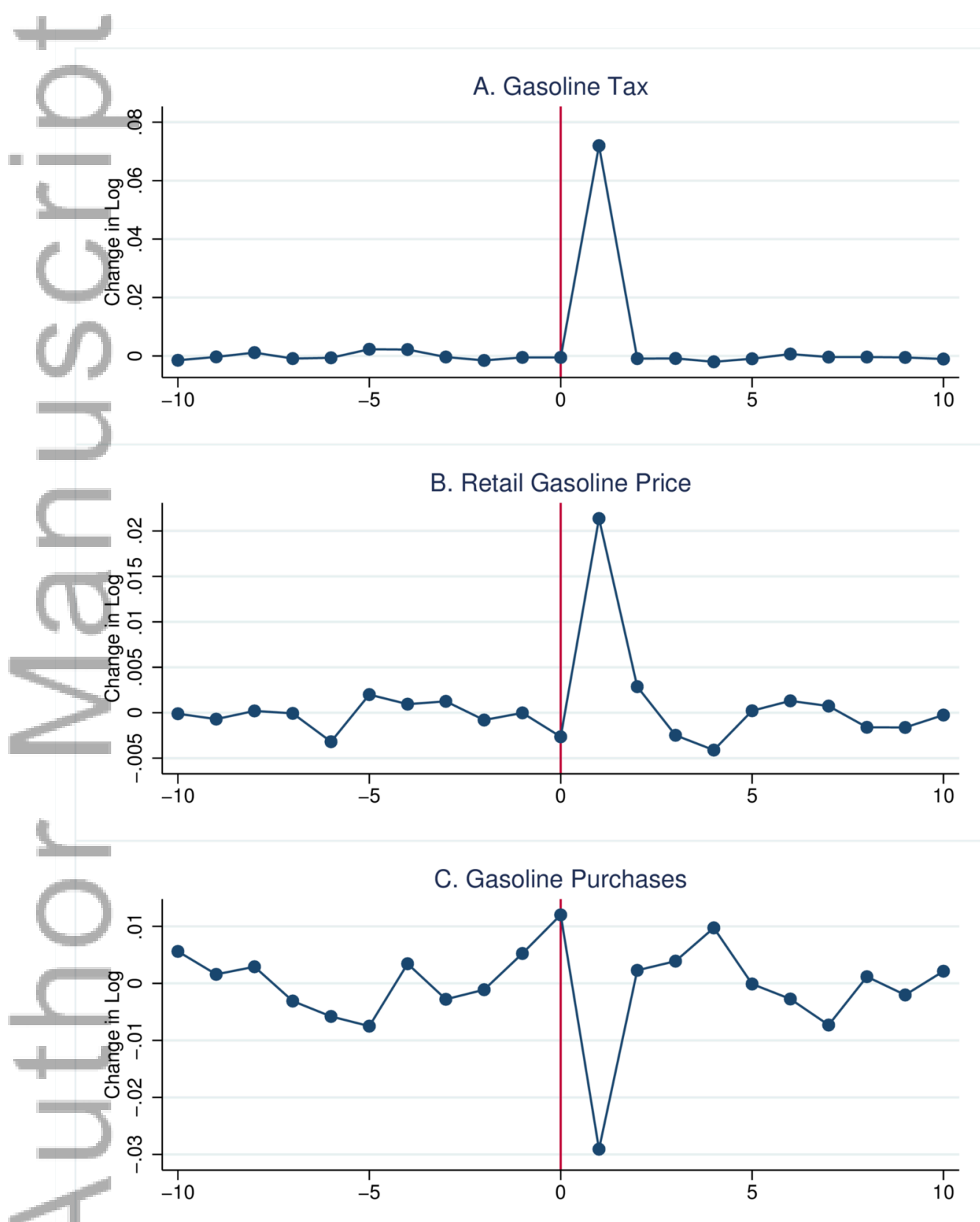

jae_2500_f2a

This article is protected by copyright. All rights reserved. 

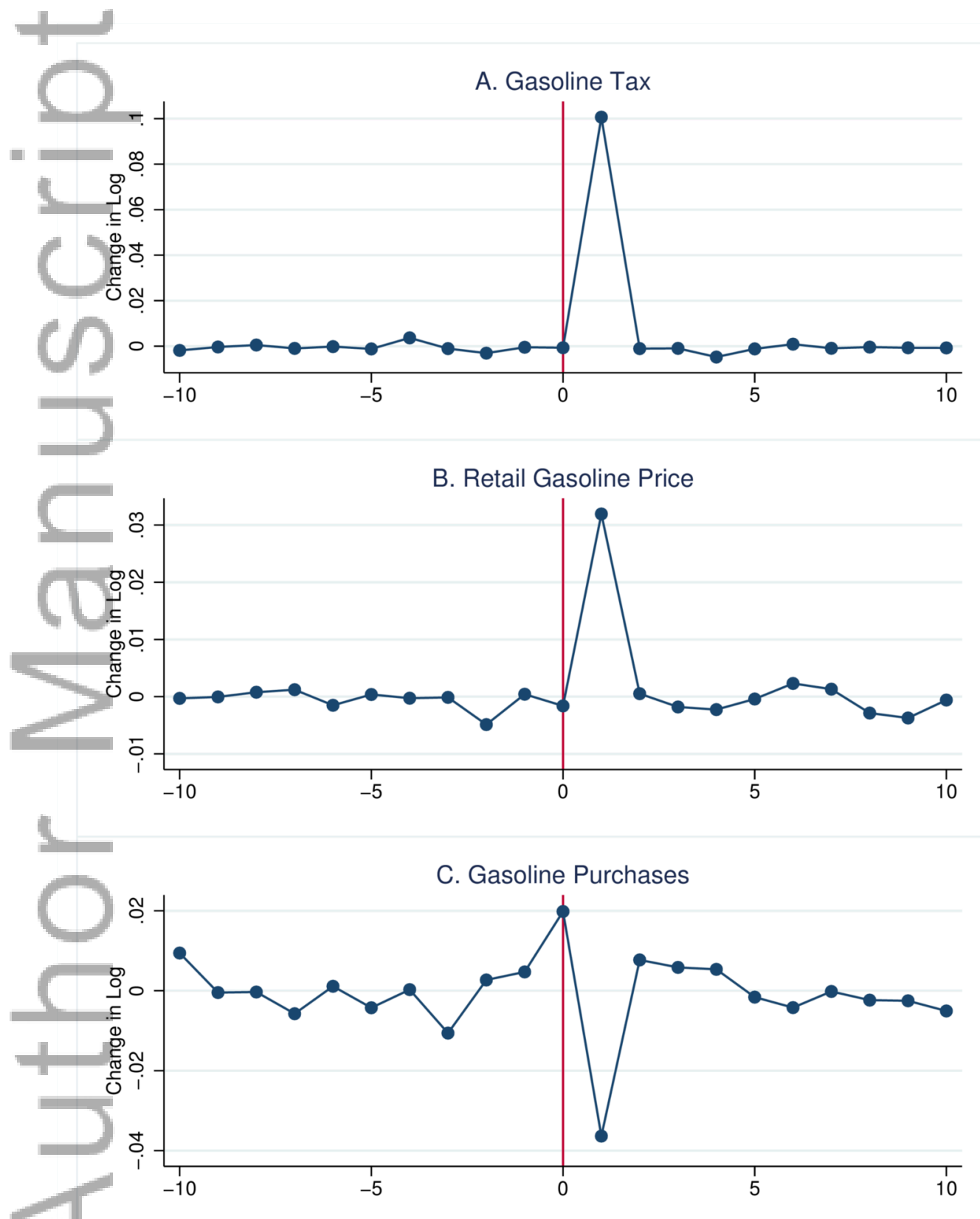

jae_2500_f2b

This article is protected by copyright. All rights reserved. 


\section{W) WILEY \\ FORM FOR TRANSMISSION OF APPROVED MANUSCRIPTS \\ PLEASE COMPLETE AS FULLY AS POSSIBLE}

Editor-please keep a copy

To: John Wiley \& Sons, Ltd., Journals Production Department, Baffins Lane, Chichester, West Sussex PO19 1UD, U.K. Telephone: +44 (0)1243 779777, Fax: +44 (0)1243 770379

\section{FOR WILEY USE}

WIP CODE _ Volume _ Issue _ Folios _ Line Figs _ H/t Figs _ Estimated Pages _

Comments<smiles>C[PH]</smiles>

EDITOR'S DETAILS

Full Journal Title Journal of Applied Econometrics.

Submitting Editor's Name Fabio Canova.

Date 9-Dec-15 Submitting Editor's code for article $\underline{\mathbf{9 6 3 5}}$

\section{MANUSCRIPT DETAILS}

The enclosed Regular has been accepted for publication.

Full Title Anticipation, Tax Avoidance, and the Price Elasticity of Gasoline Demand

Contributors' Names John Coglianese, Lucas Davis, Lutz Kilian and James Stock.

Running Headline Anticipation and Gasoline Demand.

All Original Artwork Enclosed? Yes

Ms Received on: 18-Feb-15 Revised on: 21-Aug-15 Accepted on: 11-Sep-15.

Summary attached? Yes

Key words attached? Yes

COPYRIGHT TRANSFER AGREEMENT ENCLOSED? No

\section{CORRESPONDENCE DETAILS}

Author's Proofs to be sent to:

Name: Dr. John Coglianese .

Address: Littauer Center, Room 200

1805 Cambridge Street

Cambridge MA 02138

United States

Telephone: $\underline{\mathbf{( 3 3 9 ) 3 6 8 - 1 4 8 0}}$

Fax:

Email: coglianese@fas.harvard.edu

\section{SPECIAL INSTRUCTIONS}

Disk Enclosed? No

Artwork to be returned? No

\section{COMMENTS}

An online appendix is included with this manuscript.

SIGNED Thomas Gaston
Correspondence address if different:

Name:

Address:

Telephone: 